\title{
高酸素圧示差熱分析装置による $\mathrm{CrO}_{2}$ 生成過程の解析
}

(1974 年 8 月 14 日受理)

並 河建・佐 藤実*

磁気記録材としてすぐれた特徴を有する $\mathrm{CrO}_{2}$ 粉末は, $\mathrm{CrO}_{3}$ を高圧酸素中で水熱分解することによ って得られる。また水酸化ク口ム(III)を高圧酸素中で脱水酸化して $\mathrm{CrO}_{2}$ をうる方法についても研究が 行なわれている。本実験では高圧酸素下で測定可能な DTA 装置を試作し, これを用いて高温, 高圧中 で $\mathrm{CrO}_{3}$ および $\mathrm{Cr}(\mathrm{OH})_{3}$ などより $\mathrm{CrO}_{2}$ にいたる反応の進行過程について 倹討を加えることによっ て, $\mathrm{CrO}_{2}$ 合成に関する基礎データをらることを目的とした。

その結果, $\mathrm{CrO}_{3}$ を出発物質として測定した高酸素圧 DTA からは $\mathrm{CrO}_{2}$ の生成にともなら示差熱 ピークは得られなかった。その理由として中間生成物である $\mathrm{Cr}_{2} \mathrm{O}_{5}$ が強固に焙結した塊状物質となり， さらにこれより $\mathrm{CrO}_{2}$ 粉末が生成されるさい, 試料片と熱電対間の熱接触が不良になるため $\mathrm{CrO}_{2}$ の生 成ピークが示差熱起電力の雑音に埋もれてしまい, 明確なピークを示さないためと結論した。そこであ らかじめ調製した微粉末状の $\mathrm{Cr}_{2} \mathrm{O}_{5}$ から出発した場合には $\mathrm{CrO}_{2}$ 生成に対応する吸熱ピークをらるこ とができた。これより $\mathrm{CrO}_{2}$ 生成に対する温度ならびに酸素圧の関係を明らかにすることができた。

$\mathrm{Cr}(\mathrm{OH})_{s}$ を出発物質とした場合には，前に述べた試料と比較して DTA 曲線の形が複雑になり酸化， 還元などの化学反応と，結晶化および結晶転移などが入り混じった過程を経由して $\mathrm{CrO}_{2}$ が得られるこ とを知りえた。

\section{1 緒言}

現在 $\mathrm{CrO}_{2}$ 粉末の工業的製造法としては 無水クロム酸 $\left(\mathrm{CrO}_{3}\right)$ を高圧酸素中で水熱分解する方法が採用されて拈り，これ微量 の添加物を加觉ることによって記録用磁性粉として好適な磁気特 性を付与し，さらにCurie 温度の調節などを行なって実用に供 されている。このように高温，高圧中でなされるクロム酸化物の 分解反応の進行過程についてはもちろん，その反応機構などにつ いても不明な点が多く, $\mathrm{CrO}_{3}-\mathrm{Cr}_{3} \mathrm{O}_{8}-\mathrm{Cr}_{2} \mathrm{O}_{5}-\mathrm{CrO}_{2}-\mathrm{Cr}_{2} \mathrm{O}_{3}$ 括よび $\mathrm{Cr}(\mathrm{OH})_{3}-\mathrm{CrOOH}-\mathrm{CrO}_{2}-\mathrm{Cr}_{2} \mathrm{O}_{3}$ のような一連の高酸素圧反応につ いてはいまた十分な知見が得られていない。このような高圧下に 扣ける反応機構の解析に必要な基礎データをらるために, 高圧酸 素下での示差熱分析法は有用な一手段であると考兄られる。

Cr-O 系の反応について常圧下での DTA 測定はいくつか報 告1) 3)されているが，常圧下での $\mathrm{CrO}_{3}$ 分解反応の過程において は $\mathrm{Cr}_{2} \mathrm{O}_{5}$ 相から直接的に $\mathrm{Cr}_{2} \mathrm{O}_{3}$ 相へ反応が進み, $\mathrm{CrO}_{2}$ 単一相 の領域を検知することができないためか，いずれの報告において も常圧下では $\mathrm{Cr}_{2} \mathrm{O}_{5}$ から $\mathrm{CrO}_{2}$ 相への転移に対応するピークは 認められない(4)6。

* 東京工業大学工学部, 152 東京都目黒区大岡山

1) B. Kubota, E. Hirota, National Tech.Rep., 7, 372(1962).

2) T. V. Rode, "Thermal Analysis", (J. P. Redfern, ed.), Macmillan, London (1965) p. 122.

3) T. V. Rode, "Kislorodnye Soedineniya Khroma ; Khromovye Katalizatory", Izd. Akad. Nauk SSSR, Moscow (1962).

4) Vesenin, Zh. Obshch. Khim., 17, 450 (1947).

5) G. V. Malinin et al., Kinet, Katal., 12, 234 (1971).
以上の諸点を勘案して高环酸素中での $\mathrm{Cr}-0$ 系反応について DTA の測定を行ない，その結果について検討を加えた。

\section{2 実験}

\section{1 高圧 DTA 装置}

本実験では出発物質として用いる $\mathrm{CrO}_{3}$ の強い酸化力に耐之, さらに高酸素圧にも十分耐之る必要性から高圧反応容器の材質に は超硬合金ハステロイCを用いた。装置の概略は図 1 (a)に示し た。試料室の内容積は $30 \mathrm{ml}$ で, 容器内の圧力はブルドンゲー ジによって指示される。酸素圧の調整は $150 \mathrm{~atm}$ までの範用で は加熱前に酸素ボンベから直接高圧容器に圧入することにより行 ない，それ以上の圧力範囲では酸素の液化法によった。すなわち あらかじめ液体窒素中で泠却した高圧容器中に酸素ガスを導入し て, 酸素を液化することにより, 高酸素圧の確保と不純ガスの混 入防止とをはかった。本装置に颃いては温度上昇にともなら酸素 圧変化は無視している。

DTA 測定用の 2 組の熱電対 $\mathrm{C}_{1}, \mathrm{C}_{2}$ は外径 $1.0 \mathrm{~mm}$ の耐圧性 シーズ型（18-8 ステンレスシーズ）クロメル・アルメル熱電対を 用い，反応容器上部に取りつけたブロックに銅ガスケットにより これを封入し，高圧に耐兄るようにした。試料ホルダーは図 1 （b）に示すよらな構造（18-8 ステンレススチール）となし, 熱 電対 $\mathrm{C}_{1}, \mathrm{C}_{2}$ を強い酸化䨌囲気加ら保護するため二重構造とした。 すなわち上蓋部に銀口ウ付けによって固定した外径 $2 \mathrm{~mm}$ ，内径 約 $1.2 \mathrm{~mm}$ のステンレス製試験管に測定用熱電対の 感熱部が挿 入できるようになっている。

反応系の温度制御は容器本体の外壁部に設けた小孔 $\mathrm{C}_{3}$ 内に独 


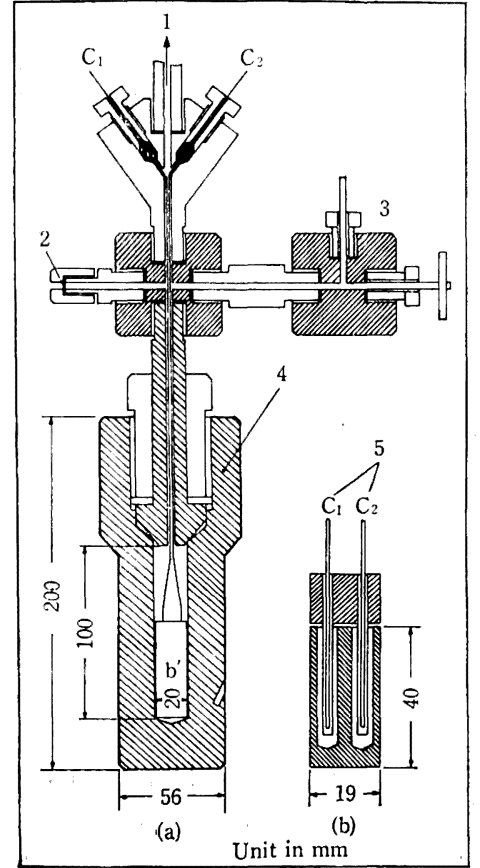

Fig. 1 (a) DTA apparatus used under high pressure (b) DTA sample holder

1 : Bourdon gauge, 2 : Rupture, 3 : Needle valve,

$4:$ High-pressure bomb, $5:$ Thermocouple

立に装着したクロメル・アルメル熱電対によって検出し，これを 電気师の制御回路に帰還して自動的に一定速度で昇温できるよう にしてある。なお図1（a）に示した容器本体部の下部から 200 $\mathrm{mm}$ までの部分が電気炉内に指入される。

\section{2 出発物 僙}

一級試薬の無水クロム酸 $\left(\mathrm{CrO}_{3}\right)$ およびつぎのように調製した 水酸化ク口ム (III) $\left(\mathrm{Cr}(\mathrm{OH})_{3}\right)$ を出発物質として実験を行なった。 $\mathrm{Cr}(\mathrm{OH})_{3}$ は $1 \mathrm{~mol}$ の $\mathrm{Cr}\left(\mathrm{NO}_{3}\right)_{3}$ 溶液をかきまぜながら $10 \%$ $\mathrm{NH}_{4} \mathrm{OH}$ を十分に加え，コロイド状溶液として調製した。コロイ ド溶液に加えた過剩のアンモニアは加熱により取り除さ，汇過し たのち真空定温槽 $\left(100 \sim 120^{\circ} \mathrm{C}\right)$ 中に 24 時間放置し, 乳バチで 十分粉砕したるのを出発物質とした。

標準物質としては $\mathrm{CrO}_{3}$ を $800^{\circ} \mathrm{C}$ 以上で長時間加熱分解して 得た安定な $\mathrm{Cr}_{2} \mathrm{O}_{3}$ 粉末を用いた。

\section{3 測 定}

測定試料および標準物質の量はおの括の約 $500 \mathrm{mg}$ とした。試 料のつめ方は得られる DTA 曲線の形に影響をおよぼす重要な因 子であるが，本実験では Kissinger6) が実施している試料容器外 壁を軽くたたくだけのルーズなつめ方を採用した。測定開始時の 反応容器内の酸素压は常圧 $\left(P_{\mathrm{O}_{2}}=0.2 \mathrm{~atm}\right)$ から約 $700 \mathrm{~atm}$ ま でとし，温度は $100 \sim 600^{\circ} \mathrm{C}$ ま゙の範囲にわたって測定した。昇 温速度は DTA 曲線のピーク位置, 感度および分解能に密接な関 係があるが，本笑験に括ける $\mathrm{CrO}_{2}$ 相生成過程はかなり緩慢な反 応である点を考虑して $4^{\circ} \mathrm{C} / \mathrm{min}$ で昇温した。示差熱感度は \pm 250 $\mu \mathrm{V}$ である。

得られた発熱および吸熱の示差熱ピークに対応する試料の構造 解析は, 高温 X線によるのが一般であるが, 高圧容器内の物質に おいては測定不可能であるため，示差熱ピーク点直前に昇温をと

6) H. E. Kissinger, Anal. Chem., 29, 1702 (1957).
め，すみやかに室温まで泠却して得られた試料に対して，X線分 析による生成物の同定を行なった。

\section{3 実験結果と考察}

\section{$3.1 \mathrm{CrO}_{3}$ を出発物質とした場合}

酸素圧 $0.2 \sim 700 \mathrm{~atm}$, 温度範囲 $100 \sim 500^{\circ} \mathrm{C}$ の反応条件下で 得たDTA 曲線を図 2 に示した。図中の圧力範囲とは，たとえ ば 650〜700 atm とあるのは初期の生力を $650 \mathrm{~atm}$ に設定して測 定を開始した場合横軸の温度範囲で $700 \mathrm{~atm}$ まで上昇したこと を表わし，この圧力変化は反応物からの分解圧，温度上昇にとる なら容器中の気体の膨脹などによるるのである。

$200^{\circ} \mathrm{C}$ 付近に現われる鋭い吸熱ピークは $\mathrm{CrO}_{3}$ の部分的な解離 をともなら融解によるものと解釈されるが，このピーク温度は反 応時の压力にあまり依存していない。300 350 ${ }^{\circ} \mathrm{C}$ 付近の発熱ピ 一クは $\mathrm{Cr}_{2} \mathrm{O}_{5}$ 相への結晶化過程によることはX 線分析の結果明ら かとなった。また $490^{\circ} \mathrm{C}$ 以上に見られる吸熱ピークは $\mathrm{Cr}_{2} \mathrm{O}_{3}$ へ の転移を示するのであった。図 2 (b) に打けるDTA 曲線には な拈 $\mathrm{Cr}_{2} \mathrm{O}_{3}$ 相への転移ピークが観測されるが，それ以上の酸素圧 すなわち（c），(d) の DTA 曲線に执いてはこの転移はさらに 高温側で起こるすのと推測される。眓 $2(\mathrm{c}),(\mathrm{d})$ の場合にはこ のピークを認めることはできなかった。

本実験の解析目標である $\mathrm{CrO}_{2}$ 相の生成に対応するピークは, どのような圧力範囲に持ける DTA 曲線においてる観測され得な かった。しかし $200 \mathrm{~atm}$ 以上の高酸素圧（図 2 (c)，(d)）の場 合に $300^{\circ} \mathrm{C}$ 近辺の発熱ピークより高い温度範囲に扣いて低酸素 圧の場合には見られなかった小刻みな微小ピークが断続して現わ れ, これらの微小ピークはつぎのよらな理由で $\mathrm{CrO}_{2}$ 相生成に関 係あるあのと考えられる。

i ）この範囲で炉を急冷し，反応を停止して得た生成物につい

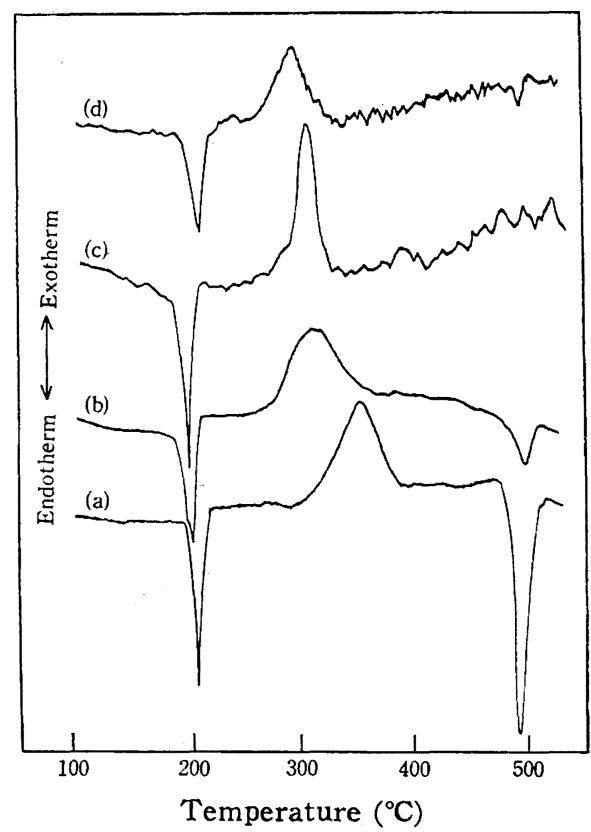

Fig. 2 DTA curves of thermal decomposition of $\mathrm{CrO}_{3}$ under various pressures

Pressure of oxygen (atm) -

(a ): 0.2 , (b ) : 95 130, (c ) : 200 400,

(d) : $650 \sim 700$ 
てX線分析を行なった結果, いずれるほぼ $\mathrm{CrO}_{2}$ 単一相であるこ とを確認した。

ii） $300^{\circ} \mathrm{C}$ 付近のピーク以下の温度範囲で得られる生成物は $\mathrm{X}$ 線的にはほぼ完全な $\mathrm{Cr}_{2} \mathrm{O}_{5}$ 相になっているが，その性状はかな り焼結の進んだ塊状であるか，または器壁に密着した強固な層状 となっているのに対して，これらをさらに $\mathrm{CrO}_{2}$ 相が生成する温 度範囲まで昇温して反応を進めると完全に独立した個々の粒子か らなる微粉末となる実験事実より，この間の転移には機珹的な性 状変化による焼結体のひびわれや，器壁よりの脱離なとによる微 細化，さらに再結晶などによる $\mathrm{CrO}_{2}$ 微粒子の生成過程が随伴す るすのと考えられる。

よって $\mathrm{CrO}_{2}$ 相への転移に対応する明確な単一ピークが現われ ないのは ii）項に挙げた状態が断続的にくり返される間に $\mathrm{CrO}_{2}$ 相の生成がなされるが，このような状態においては熱電対と試料 との熱的接触が不良になるため小刻みの微小ピークが観測される るのと推考される。他の理由としては $\mathrm{Cr}_{2} \mathrm{O}_{5}$ から $\mathrm{CrO}_{2}$ への反 応に和ける熱収支がきわめて小さいこともその一因として考觉ら れよら。

そこで ii）項の推論に基ついて DTA 曲線が不明確となる影 響を極力回避するためつぎのような新手法を案出して実験した。 すなわちまず常圧下に括いて $\mathrm{CrO}_{3}$ を $350^{\circ} \mathrm{C}$ に加熱して $\mathrm{Cr}_{2} \mathrm{O}_{5}$ とし, 得られた塊状の $\mathrm{Cr}_{2} \mathrm{O}_{5}$ をメノー乳バチで十分粉砕して得た 微粉末状の $\mathrm{Cr}_{2} \mathrm{O}_{5}$ を高酸素圧 DTA 測定用の出発材料とした。 図3はその結果得られた DTA 曲線である。別にピーク近傍で昇 温を停止し，急冷して得た試料のX線分析結果を図 4 亿示した。 因 3 (a) の場合を除き，どの曲線においてす3 箇所に明らかな吸 熱ピークが見られる。るっとも高温側の吸熱ピークはさきの実験 から明らかなよらに $\mathrm{Cr}_{2} \mathrm{O}_{3}$ 相への転移ピークである。250 ${ }^{\circ} \mathrm{C}$ 付近 に現われる吸熱ピークは図 4 (a)，(b) の回折線比較より出発物 質中にわずかに混入していた $\mathrm{Cr}_{3} \mathrm{O}_{8}$ (図 4 (a) 飞执いてもっとも 低角度側飞現われている回折線が $\mathrm{Cr}_{3} \mathrm{O}_{8}$ の最強線に対応してい

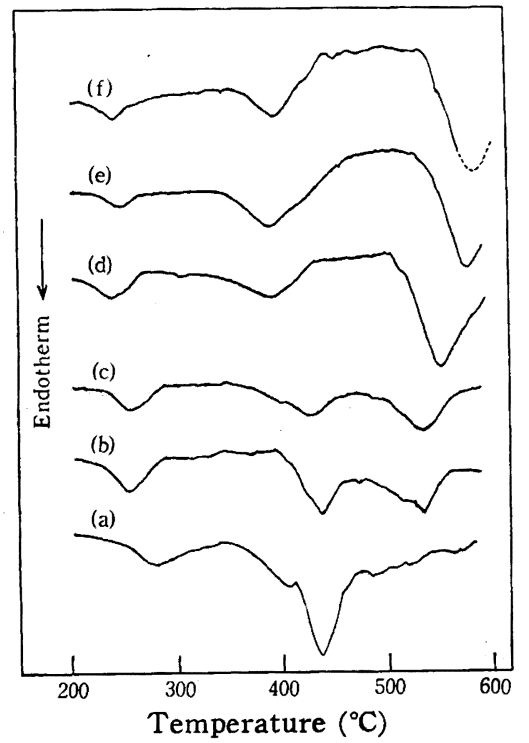

Fig. 3 DTA curves of thermal decomposition of $\mathrm{Cr}_{2} \mathrm{O}_{5}$ under various pressures

Pressure of oxygen (atm) -

(a) : 0.2 , (b) $: 50 \sim 60$, (c) $: 90 \sim 120$, (d) $: 280$

$\sim 360$, (e) $: 430 \sim 600$, (f ) $: 570 \sim 670$

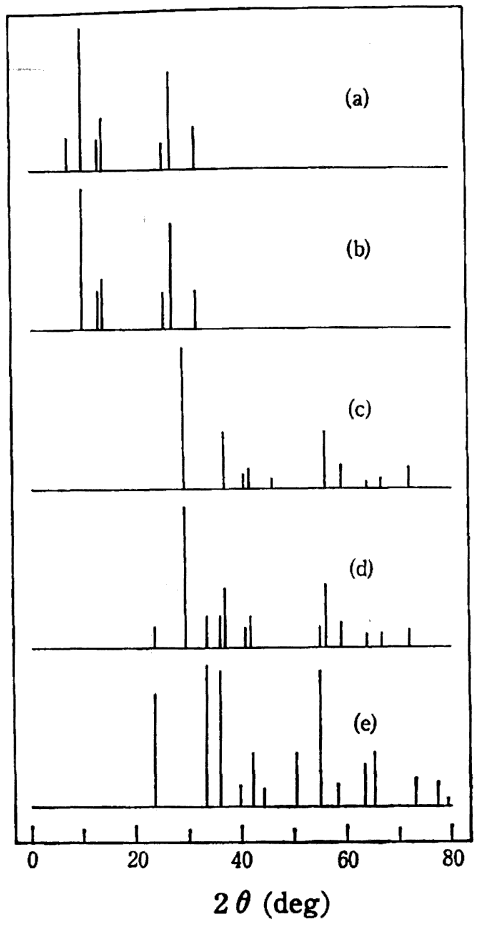

Fig. $4 \mathrm{X}$-ray diffraction patterns of chromium oxide

(a) : Starting material, (b) : $\mathrm{Cr}_{2} \mathrm{O}_{5} ; 320^{\circ} \mathrm{C}$,

(c) : $\mathrm{CrO}_{2} ; 430^{\circ} \mathrm{C} ; 700 \mathrm{~atm}$,

(d) $: \mathrm{CrO}_{2}+\mathrm{Cr}_{2} \mathrm{O}_{3} ; 430^{\circ} \mathrm{C} ; 80 \mathrm{~atm}$, (e ) $: \mathrm{Cr}_{2} \mathrm{O}_{3} ; 570^{\circ} \mathrm{C}$

る）が解離して $\mathrm{Cr}_{2} \mathrm{O}_{5}$ となったためのるのと考えられる。4 430 ${ }^{\circ} \mathrm{C}$ 付近の吸熱ピークは图 4 (c) の回折結果に見られるように $\mathrm{CrO}_{2}$ 単相であることから, このピークは $\mathrm{Cr}_{2} \mathrm{O}_{5}$ から $\mathrm{CrO}_{2}$ への 還元によるものと推考した。しかし酸素圧 $80 \mathrm{~atm}$ 以下の反応に よって得られたものは， $\mathrm{X}$ 線回折の結果から $\mathrm{CrO}_{2}$ と $\mathrm{Cr}_{2} \mathrm{O}_{3}$ の 混合物になっていることが知られた。 DTA 曲線についても約 $120 \mathrm{~atm}$ 以下 (図 3 (a)，(b)，(c)) では $\mathrm{CrO}_{2}$ 相の生成ピーク の直後から引きつづいて $\mathrm{Cr}_{2} \mathrm{O}_{3}$ の生成による吸熱反応が始まり, 二つの吸熱ピークが重畳するため，これらのピーク間の温度範囲 に拈いても $\mathrm{CrO}_{2}$ の単相は得られないことが考えられる。とくに 常圧 (0.2 atm) に拈いては $\mathrm{Cr}_{2} \mathrm{O}_{3}$ ピークの 開始温度付近にわず かに $\mathrm{CrO}_{2}$ 生成のためと思われるピークが認められるのみであ る。

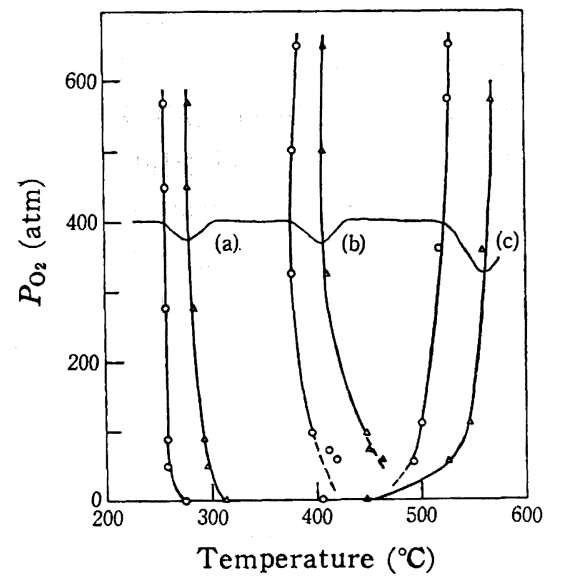

Fig. 5 DTA peaks as a function of oxygen pressure (a ) $: \mathrm{Cr}_{2} \mathrm{O}_{5}$, (b ) $: \mathrm{CrO}_{2}$, (c) $: \mathrm{Cr}_{2} \mathrm{O}_{3}$ 
つぎに図 3 の DTA 曲線のデータから吸熱ピークの温度と酸素 圧との関係を図 5 に示す。この図から DTAの手法を用いてCr-0 系に関する状態図類似の関係をらることがでさ, $\mathrm{CrO}_{2}$ の生成範 囲の概略を明らかにすることがでさた。この結果は窪田ら ${ }^{1)}$ の報 告による平衡温度, 平衡圧力に関する契験で得た $\mathrm{CrO}_{3}$ の熱分解 による $\mathrm{Cr}-\mathrm{O}$ 系の状態図ともかなりよい一致が得られた。このこ とは平衡状態で行なら実験にくらべて DTA のデータをもとにす ると比較的簡単に状態図類似の関係を描くことがでさ, $\mathrm{Cr}_{2} \mathrm{O}_{5}$ か ら $\mathrm{CrO}_{2}$ への反応は吸熱であることが明らかになった。

\section{2 出発物質として非晶質 $\mathbf{C r}(\mathbf{O H})_{3}$ を使用した場合}

$\mathrm{X}$ 線的に非晶質の $\mathrm{Cr}(\mathrm{OH})_{3}$ を出発物質として反応を進めた場 合の DTA 曲線を図6 6 に示す。 $\mathrm{CrO}_{3}$ および $\mathrm{Cr}_{2} \mathrm{O}_{5}$ を出発物質と した場合に比較して DTA 曲線はかなり複雑になっており，常圧， $100 \sim 120,560 \sim 730 \mathrm{~atm}$ の各酸素压で得られた曲線は相互にか なり異なったようすを示している。そこでそれぞれの圧力におい て示差熱ピーク直前で昇温をとめ, 急冷して得た物質についてX 線分析，化学分析特よび磁気測定を実施し，いかなる反応に基づ くピークかについて検討を行なった。常圧の場合には示差ガス分 析 (DGA) を合わせ行ない, 解析を進めた。

常圧においては非晶質 $\mathrm{Cr}(\mathrm{OH})_{3}$ はまず 200 ～ $300^{\circ} \mathrm{C}$ できわめ て緩慢な脱水が起こり, $380^{\circ} \mathrm{C}$ で急激に $\mathrm{Cr}_{2} \mathrm{O}_{3}$ 相への結晶化が行 なわれている（図6 (a))。

つぎに 100〜120 atm に括ける DTA 曲線の解析を試みた（図 $6(\mathrm{~b}))$ 。この圧力の下で $250^{\circ} \mathrm{C}$ で反応をとめた試料は褐色で水 を含み湿った状態であった。X線分析の結果ではいぜんとして非 晶質の状態にあり，結晶解析はできなかったが，化学分析から $\mathrm{Cr}(\mathrm{OH})_{3}$ の一部が酸化し $\mathrm{H}_{2} \mathrm{CrO}_{4}$ になっていることがわかった。

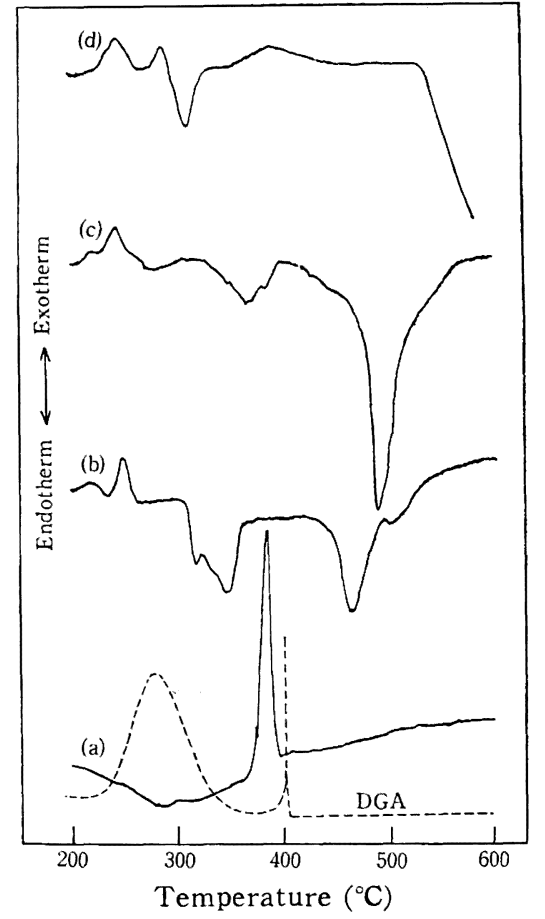

Fig. 6 DTA curves of thermal decomposition of amorphous $\mathrm{Cr}(\mathrm{OH})_{3}$ under various pressures

Pressure of oxygen (atm) -

(a ) : $0.2, \quad$ (b ) : $100 \sim 120$, (c ) : 320 350,

(d) : $560 \sim 730$
よって $250^{\circ} \mathrm{C}$ に打ける発熱ピークは $\mathrm{Cr}(\mathrm{OH})_{3}$ 粒子の部分酸化に 対応するるのと思われる。 $300^{\circ} \mathrm{C}$ 近辺から始まる吸熱と゚ークは主 として $\mathrm{Cr}(\mathrm{OH})_{3}$ 扰よび混在する微量の $\mathrm{H}_{2} \mathrm{CrO}_{4}$ の脱水反応によ るものと考えられる。またピークが二つ観察されるのは脱水直後 に菱面体晶系の $\mathrm{HCrO}_{2}$ への結晶転移による発熱ピークが脱水ピ ークに重畳したるのと解釈できる。 $420^{\circ} \mathrm{C}$ で得た試料については 磁気測定の結果からわずかに $\mathrm{CrO}_{2}$ の存在を認めることができ た。これはさきの $\mathrm{Cr}^{6+}$ が還元して $\mathrm{Cr}^{4+}$ となり $\mathrm{CrO}_{2}$ が得られ たものと思われるが，反応してできた物質の割合がごくわずかで あるためピークとしては観測されないるのと推定される。最後の 吸熱ピークは微量に存在する $\mathrm{CrO}_{2}$ の還元と $\mathrm{HCrO}_{2}$ の脱水によ りほとんど $\mathrm{CrO}_{2}$ 相になることなく值接 $\mathrm{Cr}_{2} \mathrm{O}_{3}$ 相へ転移する反 応とが混成された結果であろらと思われる。

560 730 atm の圧力範囲に批ける DTA 測定の結果 (図6 (d)) はさきに述べた低圧反応の結果とピークの形やピーク温度などに 若干の相違点が見られる。すず $250^{\circ} \mathrm{C} に$ 現われる発熱ピークは 非晶質 $\mathrm{Cr}(\mathrm{OH})_{3}$ の結晶化によるあのであり, その後一部が $\mathrm{Cr}^{6+}$ に酸化するものと思われる。しかし大部分の $\mathrm{Cr}(\mathrm{OH})_{3}$ 結晶粒子 は脱水をともないながら, $\mathrm{CrOOH}$ (斜方晶) 系相へ転移し,さら に $\mathrm{HCrO}_{2}$ (菱面体晶系) 相へと転移が進行してゆくが, $400^{\circ} \mathrm{C}$ 付 近に微弱な発熱ピークが現われているのは高酸素圧中で一部の $\mathrm{Cr}^{3+}$ が酸化し $\mathrm{CrO}_{2}$ が生成するためのピークと考えられる。

図 7 に $\mathrm{Cr}(\mathrm{OH})_{3}$ から出発した場合の DTA 結果から推測され る分解過程を $\mathrm{CrO}_{3}, \mathrm{Cr}_{2} \mathrm{O}_{5}$ から出発した場合の結果と合わせて示 した。図中に二重線で示した径路は実験の結果から主反応と見な しうる過程である。

上に述べた点から明らかなように常圧下での $\mathrm{Cr}(\mathrm{OH})_{3}$ の分解 過程に拈いては， $\mathrm{CrO}_{2}$ 相を経過することなく直接 $\mathrm{Cr}_{2} \mathrm{O}_{3}$ へ反応 が進行し， $\mathrm{CrO}_{2}$ をうることができない。数十気圧以上 $300 \mathrm{~atm}$ 程度までの圧力範囲に括ける反応ではいったん 6 価に酸化した $\mathrm{H}_{2} \mathrm{CrO}_{4}$ を経て，わずかに $\mathrm{CrO}_{2}$ をらることができたが，脱水後 の 3 価のクロム化合物をさらに酸化することによって $\mathrm{CrO}_{2}$ をう ることはできなかった。500 atm 以上の反応においては 3 価ク口 么の脱水酸化が起こりかなり純度の高い $\mathrm{CrO}_{2}$ をらることができ た。

以上のように DTA 測定では動的に反応過程を追ったものであ り, 反応速度論的考察は加えられていない。したがって $\mathrm{Cr}(\mathrm{OH})_{3}$ より出発する $\mathrm{CrO}_{2}$ 合成法として, 数百気圧以下です, $250^{\circ} \mathrm{C}$ 付近 の温度に長時間たもつことによって $\mathrm{Cr}^{3+} \rightarrow \mathrm{Cr}^{6+}$ の反応を十分進 行させ, 引きつついて $400^{\circ} \mathrm{C}$ ま昇温することによって合成が 可能となることが考えられるが，それ以上の高圧下で反応を進め れば $\mathrm{HCrO}_{2}$ の脱水酸化が可能になり,より純度の高い $\mathrm{CrO}_{2}$ を合 成することがでさるものと思われる。

\section{4 結 論}

実験結果を要約するとつぎのとおりである。

1） $\mathrm{CrO}_{3}$ を出発物質として反応を進めた場合の DTA 曲線に 拈いては $\mathrm{CrO}_{2}$ 生成に対応すると考えられる明瞭な示差熱と゚ーク は得られなかった。これは $\mathrm{CrO}_{2}$ が生成すると思われる酸素圧お よび温度範囲で $\mathrm{Cr}_{2} \mathrm{O}_{5}$ が焼結の進んだ塊状物質になり反応の進 行にともない, このような塊状物が機械的な崩壊作用を起こし微 粉化する過程において，熱電対との間で熱的な接触不良をきたす 


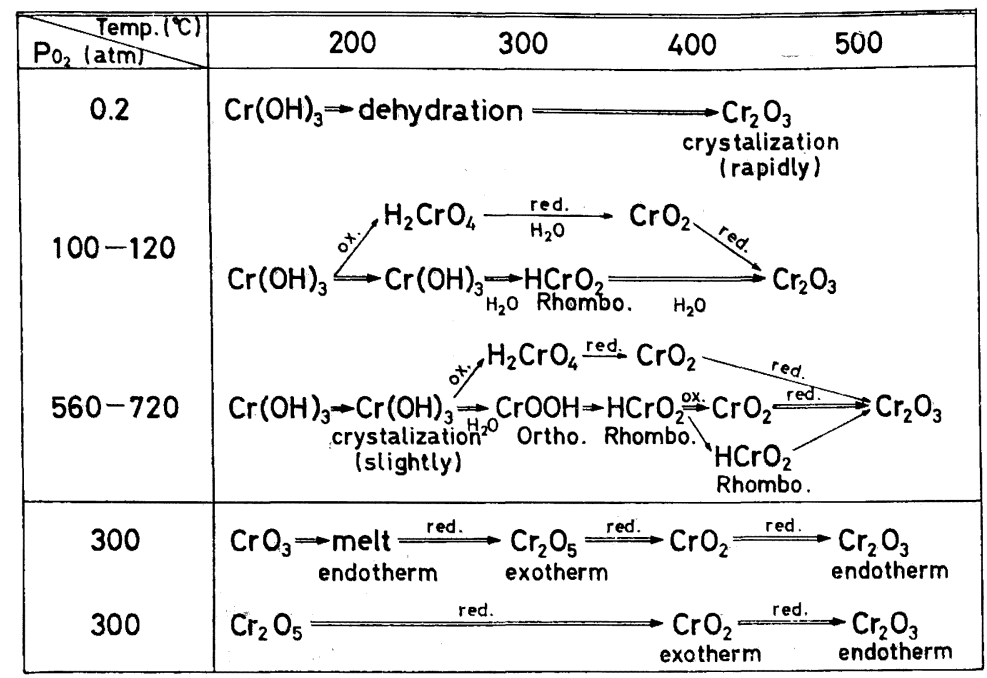

Fig. 7 Decomposition process of $\mathrm{Cr}(\mathrm{OH})_{3}, \mathrm{CrO}_{3}$ and $\mathrm{Cr}_{2} \mathrm{O}_{5}$

ため曲線の乱れを生じ, 明膫なピークを示し得ないるのと考えら れる。

2) $\mathrm{Cr}_{2} \mathrm{O}_{5}$ 粉末を出発物質とした場合には $\mathrm{CrO}_{2}$ の生成に対応 する吸熱ピークを䏰めることができた。これから $\mathrm{CrO}_{2}$ の生成範 囲を示差熱分析の結果として明らかにすることができた。

3）非晶質 $\mathrm{Cr}(\mathrm{OH})_{3}$ を出発物質として得た DTA 曲線につい ては酸素圧の值により反応過程を三段階にわけて考察を加兄るこ とが合理的であると結論した。すなわち本実験の昇温速度では常 压に扔いて $\mathrm{CrO}_{2}$ 相を経ることなく, 反応は $\mathrm{Cr}_{2} \mathrm{O}_{3}$ 相に進行して しまう。200 400 atm に拉いては一部 6 価に酸化した $\mathrm{H}_{2} \mathrm{CrO}_{4}$ を経て $\mathrm{CrO}_{2}$ が生成されるが， 3 価から 4 洒偪直接酸化されるこ
とはない。500 atm 以上において, 初めて $\mathrm{CrO}_{2}$ の単相をうるこ とができる。

4）本実験では反応速度論的な考察は行なわなかったが，DTA の昇温速度を変化させるなど，その他の手法で今後検討を加兄る 予定である。

5）本实験にさいし試作した高圧 DTA 装置を用いることによ り種々の物質に対する高压反応 (1 1000 atm) の熱收支を比較的 再現性よく解析できることを確認した。

(1972 年 3 月, 電気化学協会第 39 回大会； 1973 年 5 月, 粉 体粉末治金協会昭和 48 年度春季大会発表)

\title{
Differential Thermal Analysis on the Formation Process of $\mathrm{CrO}_{2}$ under High Oxygen Pressure
}

\author{
Tatsuru Namirawa and Minoru Satou \\ Tokyo Institute of Technology; Ookayama, \\ Meguro-ku, Tokyo 152 Japan
}

It is well known that the ferromagnetic fine powder of $\mathrm{CrO}_{2}$ can be obtained by the hydrothermal decomposition of $\mathrm{CrO}_{3}$ or the dehydration and oxydation of $\mathrm{Cr}(\mathrm{OH})_{3}$ under high oxygen pressure. However, the dissociation processes of $\mathrm{CrO}_{3}$ and $\mathrm{Cr}(\mathrm{OH})_{3}$ under high oxygen pressure at elevated temperature have not been fully investigated. Moreover, the peak of DTA which shows the formation of $\mathrm{CrO}_{2}$ phase has not been fined yet under atmospheric pressure. The DTA measurement under high oxygen pressure seems to be available to elucidate the transformation process to $\mathrm{CrO}_{2}$ and the transformation temperature region.

The mechanism of the formation of $\mathrm{CrO}_{2}$ was studied by the apparatus which is specially designed for measurements under high oxygen pressure. As a starting material, $500 \mathrm{mg}$ of $\mathrm{CrO}_{3}$ was used. Although three peaks were observed under high oxygen pressure, no peak that corresponds to the formation of $\mathrm{CrO}_{2}$ was observed. It was considered that the poor thermal contact between solidified $\mathrm{Cr}_{2} \mathrm{O}_{5}$ and thermocouple made difficult to detect the $\mathrm{CrO}_{2}$ peak. To improve the thermal contact, fine powder of $\mathrm{Cr}_{2} \mathrm{O}_{5}$ was used as a starting material, so that a faint endothermic peak was observed at about $420^{\circ} \mathrm{C}$. It was confirmed by $\mathrm{X}$-ray analysis that this peak corresponds to the formation of $\mathrm{CrO}_{2}$.

When $\mathrm{Cr}(\mathrm{OH})_{3}$ was used as a starting material, the oxidation, the reduction and the crystal transformation of the specimen occurred during the dissociation process, so that the DTA curve showed more complicated behavior than that of $\mathrm{CrO}_{3}$. 